Board of Governors of the Federal Reserve System

International Finance Discussion Papers

Number 599

December 1997

\title{
Private Payments Systems in Historical Perspective: The Banco Central System of Mexico
}

\author{
Patrice Robitaille
}

NOTE: International Finance Discussion Papers are preliminary materials circulated to stimulate discussion and critical comment. References in publications to International Finance Discussion Papers (other than acknowledgment that the writer has had access to unpublished material) should be cleared with the author or authors. Recent IFDPs are available on the Web at www.bog.frb.fed.us 


\title{
Private Payments Systems in Historical Perspective: The Banco Central System of Mexico
}

\author{
Patrice Robitaille*
}

\begin{abstract}
Payments systems have grown considerably and have become increasingly complex, prompting regulators to reassess their roles and renewing interest in historical experiences with payments systems. In this paper, I study the Banco Central System of Mexico, which was a bank note par redemption and clearing system for other payments that operated in Mexico City from 1899 until 1913. I first describe the origins of the Banco Central System. I then consider whether it became prone to behavioral problems, as some observers contended. I find that although Banco Central was less well-positioned to address incentive problems relative to one of its counterparts in the United States (the Suffolk Bank of Boston), it did act to constrain bank behavior. However, considerable government intervention weakened the disciplinary role of Banco Central and thus made the system more prone to collapse.
\end{abstract}

Key words: payments systems, free banking, competitive currencies, central banking

* Economist, Division of International Finance, Board of Governors of the Federal Reserve System (robitaip@frb.gov). I thank seminar participants at Cornell University and participants in the division's Monday workshop for helpful comments. I also benefitted from conversations with several people over various stages of this research, especially with Michael Bordo, David Bowman, Mike Gibson, Ed Green, Andy Levin, Noel Maurer, Art Rolnick, Jeff Stehm, and Warren Weber. Noel Maurer generously provided me with some of the data on Mexican banks. Special thanks to Barbara Tennenbaum of the Hispanic Division of the Library of Congress and to Richard Doty of the National Numismatic Collection at the Museum of American History for their help. Bernadette Ryan provided outstanding research assistance. All quotes taken from Spanish language sources were translated by me unless otherwise indicated. The views in this paper are solely the responsibility of the author and should not be interpreted as reflecting the views of the Board of Governors of the Federal Reserve System or of any other person associated with the Federal Reserve System. 


\section{Introduction}

Over the past decade, payments systems have grown considerably and have become increasingly complex, prompting regulators to reassess their roles. ${ }^{1}$ Two controversial issues that have arisen are to what extent self-regulation can supplant government regulation and supervision and how well a completely private system could cope in times of stress. These questions have prompted some to take a closer look at historical experiences in banking. With respect to private payments systems involving bank currencies, or bank notes, at least two of them appear to have worked very well with minimal government intervention: the note exchange system that developed in Scotland during eighteenth century (White 1984, Cowen and Kroszner 1989) and the Suffolk Bank System of New England in the early nineteenth century ( Mullineaux 1987, Calomiris and Kahn 1996).

In this paper, I study a Mexican bank note redemption and payments system that was not considered successful. It started in 1899, when Banco Central Mexicano (Banco Central for short) received a federal charter to be, in part, the Mexico City correspondent for certain banks. Banco Central redeemed member bank notes for specie (gold or silver coin) at par and acted as their agent in the clearing of other payments. Because of Banco Central's role in the arrangement, I call it the Banco Central System (BCS). The BCS lasted until 1913, two years after the revolution began.

The Mexican banking system of the early 1900s was far from, as Selgin and White (1994 p. 1718) put it, a "pure laissez faire monetary regime". Throughout the late nineteenth century, Mexico's largest bank, Banco Nacional de Mexico, had a close relationship with the federal

${ }^{1}$ The Federal Reserve Board (The Rivlin Committee) has recently undertaken the task of reassessing its role in payments systems (see statement by Vice-Chair Alice Rivlin in the November 1997 Federal Reserve Bulletin). 
government and enjoyed special privileges that helped shield it from competition. Even after barriers to entry into banking were relaxed in 1896 , entry continued to be restricted for banks of issue (i.e., those that were allowed to issue demandable notes). The experience with the BCS nonetheless greatly altered the prevailing attitude in Mexico concerning the desirability of privately controlled payments systems. The belief that fraud or mismanagement was a serious problem rationalized the creation of a government-owned central bank and the banning of private bank notes.

Below, I describe the origins of the BCS and trace its experiences to its demise. I then take a closer look at the BCS. According to Manero (1957), Banco Central failed to act in ways that would have ensured the viability of the system. I find, however, that Banco Central did act to constrain the behavior of member banks. At least, it did so initially, but government intervention in the system muted Banco Central's effectiveness as a source of bank discipline. I conclude that government meddling with the system made it more prone to behavioral problems than otherwise would have been the case.

\section{Background ${ }^{2}$}

For several decades after Mexico's independence from Spain in 1820, internal turmoil and armed conflicts against external powers greatly limited economic development. The coming to power of General Porfirio Diaz in 1877 marked the beginning of an unprecedented period of

${ }^{2}$ Federal government banking records (Memorias de las Instituciones de Credito) was the main source of information for this study. It contains bank charters, shareholders' annual reports, reports from federal bank inspectors, correspondence between the federal government and banks, and other information. 
political stability that set the stage for growth and the development of the financial system. Diaz's rein lasted until 1911. (Appendix 1 describes the historical setting in greater detail.) In the early 1900s, as many as 29 Mexican banks issued demandable notes that by law had to be redeemed from the issuer for specie (gold or silver coin) at par. Banks of issue were the predominant type of depository institution, although their importance declined in the first decade, apparently because of the rising use of checkable deposits that paid interest (see Rosenzweig 1965). Banks of issue accounted for 92 percent of assets of chartered banks in 1897, and for 84 percent of their assets in 1907. These figures understate the declining importance of banks of issue to some degree because several unregulated depository institutions were established in the early 1900s, but the available information suggests that the banks of issue were still the predominant banking institutions.

Since the early 1890s, all issuers of demandable notes had been operating under federal bank charters. There were two types of banks of issue, "city" banks and "state" or "local" banks. The two city banks were based in Mexico City and were the country's two largest banks, accounting for 80 percent of the assets of the banking system in 1897. Banco Nacional de Mexico was the larger of the two, accounting for 50 percent of the assets of the banking system that year. Banco de Londres y Mexico was the other city bank. City banks were not subject to branching restrictions, whereas state banks were. State banks were not allowed to branch outside specific regions (that sometimes overlapped) and were prohibited from operating in Mexico City.

In 1896, a federal bank law was passed that succeeded, among other things, in subjecting nearly all state banks to common legal requirements. (City banks continued to operate under the terms of their charters when in conflict with the law.) The law also made nearly uniform the 
physical characteristics of all bank notes. Notes had to state the date of the issue and carry the signatures of one of the directors of the bank, its cashier or manager, and a federal government bank inspector. (Banco Nacional's notes bore the signatures of two federal government inspectors.) The minimum denomination note was 1 peso for Banco Nacional and 5 pesos for all other banks. In 1895, GDP per capita was 67 pesos. Thus, a 5-peso note was not something that the typical Mexican worker would have used in day-to-day transactions.

A bank of issue could put its notes into circulation by accepting specie or making a loan. Before an issuer could put notes into circulation, it had to follow a number of steps. The available information suggest that notes were shipped to the issuer, and then were sent on to Mexico City after a federal bank inspector was satisfied that the bank had complied with legal requirements. The notes were passed through the federal tax office (Oficina de Timbre), a part of the federal Treasury (Secretaria de Hacienda), where a note tax was paid and the notes were stamped. $^{3}$

Under the 1896 law (as well as prior to that law), notes were backed by the assets of the bank, which consisted essentially of specie reserves and risky assets. While a bank did not have to back its notes in full by specie reserves, Mexican bank law was designed to make bank notes as safe as was thought possible. Notes had a first lien on the assets of the bank, and banks had to adhere to other legal restrictions designed to protect note holders. Any issuer that could not redeem its notes at par faced liquidation. However, a bank branch was not obligated to redeem at

3 Article 967 of the 1884 Commercial Code (see Lelo de Larrea 1884) provides the only available detailed description of the steps that an issuer had to follow before putting its notes into circulation that I could find. Although the section relating to banking was removed from the commercial code several years later, it appears that the same steps continued to be followed. 
par notes put into circulation by another branch of the same bank.

Prior to the passage of the 1896 law, only a few banks of issue operated in Mexico because issuing notes required a federal bank charter, which was difficult to obtain. Moreover, a charter to be a bank of issue was of uncertain legal validity because it conflicted with Banco Nacional's 1884 charter. Banco Nacional, the federal government's fiscal agent, had been founded in 1881 as a result of the federal government's efforts to attract capital from abroad. Banco Nacional's foreign associations and the bank's efforts to enforce its special powers fueled considerable resentment against the bank throughout the latter part of the nineteenth century. (Appendix 1 discusses these circumstances further.)

In 1896, the legal dilemma was finally resolved, paving the way for the passage of a new banking law for state banks. The 1896 law relaxed entry into the business of issuing notes for state banks, but preserved their branching restrictions and resulted in there being more favorable tax treatment given to city bank notes (see Appendix 2). Tax considerations and minimum capital requirements essentially restricted entry to no more than one bank per state in most cases (see Appendix 2). By 1903, nearly every state had one chartered bank of issue based in that state, and three states had two; the number of state banks rose from 7 to 25 between 1896 and 1903, and peaked at 27 in 1905 . Tables $1 \mathrm{a}$ and $1 \mathrm{~b}$ list the state banks that received federal charters before 1896 (all of them between 1888 and 1891) and under the 1896 law.

\section{Origins of the Banco Central System}

By the late 1890s, a manufacturing sector was emerging and interregional trade was growing rapidly, spurred by the development of transportation and communications systems and the suppression of interstate tariffs (alcabadas) in 1896. Less than one thousand kilometers in 
railroad lines existed in 1880. By 1900, a 12 thousand kilometer system extended over various parts of the country from the central hub in Mexico City. Cargo transported by rail rose from 0.2 million tons in 1880 to 7.5 million tons in $1900 .{ }^{4}$ By the turn of the century, for instance, Mexico had a thriving textile industry that was heavily concentrated in the Mexico City region, mostly in the Federal District and Puebla, that received shipments of raw materials from other regions (Casasus 1905; see also Haber 1991).

The rise in interregional trade and in the number of state banks resulted in more state bank notes traveling greater distances. A consequence of these developments, as Casasus (1908) observed, was that state bank notes exchanged for specie at discounts when they were far from the issuer. Casasus observed that the discounts in Mexico City were higher for the banks in the more remote states. In contrast, all indications are that the notes of the city banks circulated throughout the country at par. Both the law and Banco Nacional's charter explicitly stated that a branch of a bank was not required to accept at par note issued by another branch of the same bank. Since 1893, though, Banco Nacional had made it a policy to do so whenever possible. ${ }^{5}$ The fact that, since 1887, only Banco Nacional's notes could be accepted by treasury agents helped support the demand for its notes, and thus boosted their value, especially since acceptance

${ }^{4}$ Data come from Instituto Nacional de Estadistica Geografia e Informatica, Estadisticas Historicas de Mexico, 1985.

${ }^{5}$ As for Banco de Londres, Martinez Sobral (1911) suggests that its notes circulated at par from the time it started operating in the 1860s (see Appendix 1). Also, El Heraldo Mexicano states on January 21, 1908 that "ten years ago, the notes of only two banks were accepted without discount"; since it was well known that state bank notes circulated at discounts around the turn of the century, the newspaper most likely was referring to the two city banks. 
was required to be at par. ${ }^{6}$

Against this background, in November 1898, representatives of thirteen local banks established the basis for the creation of a Mexico City bank. The following February, President Diaz approved a request for a charter to create a development bank in Mexico City called Banco Refaccionario Mexicano and approved the bank's statutes. A development bank (banco refaccionario) had to adhere to different rules than did the banks of issue, but the crucial distinction was that it could not issue notes. The name of the bank was shortly thereafter changed to Banco Central. Banco Central's statutes stipulated that it would enter into correspondent arrangements with state banks. Although Banco Central was expected to raise some of its capital from its members, it could also issue shares to outside investors. With the federal government's help, more than half of the bank's capital was raised from an private placement that will be described further below. After raising one half of the authorized capital, the bank began operating on February 15, 1899.

Gurza (1905) and Casasus (op. cit.) make it clear that it was intended that Banco Central redeem local bank notes in Mexico City at par. ${ }^{7}$ Gurza (op. cit. p. 49), for instance, tells us that state banks that devised the note redemption system "understood that their circulation could not

${ }^{6}$ Under Banco Nacional's 1881 charter, the bank's notes were legal tender for federal payments, but federal treasury agents were not required to accept its notes at par until its charter was renegotiated in 1884. From 1884 to 1887, federal tax agents also accepted at par the notes of another financial institution (Monte de Piedad) that had suspended convertibility during the crisis period of 1883-84. Banco Nacional's 1884 charter stipulated that Monte de Piedad would retire its notes.

7 According to Gurza (op. cit.), the Banco Central arrangement had other advantages, such as not charging members commissions on other clearings, as had been the case with previous correspondents. Conant (1911) provides conflicting information. 
be sufficiently wide and productive unless their notes were admitted at par in the capital of the Republic." Gurza thus understood that having an agent that would redeem bank notes at par in the country's financial and commercial center increased the desirability of state bank notes and added to state banks' profitability. Thus, the BCS was a collusive mechanism for extracting rent from the city banks.

In the course of its business, Banco Nacional had at times redeemed state bank notes for specie at par, but its prompt return of state bank notes for redemption was clearly unpopular (Barrera Lavalle 1909 p. 207). ${ }^{8}$ If Banco Central had not been created, Banco Nacional probably would have continued to act as a broker for state bank notes. By returning notes quickly to the issuer for redemption, Banco Nacional acted as a check on state banks and in this sense had a stabilizing effect on the banking system. However, Banco Central seemed less vulnerable to the criticism that it was anti-competitively constraining state bank note issuance. Its statutes prohibited it from operating in states where it had a correspondent relationship (which was in all states that had a state bank) and it could not issue notes.

\section{Experience under the BCS and Reform}

According to Conant (1911), the BCS seemed to work very well. Conant credited the system for enabling state bank notes to circulate throughout the country at par in the early

8 The belief that Banco Nacional's actions or even those of Banco de Londres were predatory was never stated explicitly. However, Gurza (op. cit. p. 48), quotes one anonymous observer who said that the idea of the Government was 'that the new national banking system would reduce the exploitation of the great banks of the Federal District...'. Barrera Lavalle (op. cit. p. 207) recounts conflicts that arose in the states of Veracruz and Yucatan when the branches of Banco Nacional returned local bank notes for redemption. The banks were located in these and in other states that had customs collection points were "at the mercy of the agencies and branches of Banco Nacional". 
1900s. ${ }^{9}$ The broadening of the BCS in 1904 to include a limited mutual assistance arrangement added more protection to note holders.

The BCS only survived a financial crisis in 1907-08, however, because of the financial assistance that was provided by Banco Nacional and the Mexican government. The crisis was marked in part by the restructuring of two banks in the state of Yucatan by Banco Central and Banco Nacional and from an apparent injection of new capital by shareholders of Banco Nacional (discussed below). Banco Nacional also responded by agreeing to accept at par the notes of two other state banks (Banco de Campeche and Banco de Michoacan) that were in trouble (Maurer 1997). Finally, in the fall of 1908, the Mexican government also provided Banco Central, Banco Nacional, Banco de Londres, and another large bank with a considerable amount of financial assistance (see Conant op. cit). ${ }^{10}$

Although Banco Central apparently also continued to accept state bank notes for specie at par throughout the crisis, as of 1909, outside Mexico City, some state bank notes could be exchanged for specie only at discounts (Schell 1996 p. 82 fn 72). Judging from McCaleb (1920), Banco Central continued to redeem state bank notes in Mexico City at par until 1913, two years

${ }^{9}$ Federal bank examiners often noted the discount rates of bank drafts ("giros") on distant localities, which suggests that the Banco Central System was not intended to and did not support par check clearing.

${ }^{10}$ Help in 1908 had come in the form of the creation of the Caja de Asistencia para Obras de Fomento e Irrigacion, whose government-guaranteed bonds were marketed abroad in the fall of that year. The federal government, Banco Central, Banco Nacional, and two other large banks held portions of the Caja's shares (the bank was capitalized at 10 million pesos). The proceeds from the bond sales, which totaled about 44 million pesos, were swapped at par for loans of the four banks that presumably were not likely to be repaid in full. 44 million pesos amounted to 20 percent of the paid in capital and reserves of the banking system as of March 1908 , defined to include banks of issue and regulated depository institutions. 
after the revolution began, and after many banks suspended the convertibility of their notes into specie (Kemmerer 1940). The following November, the Mexican government formally made bank notes inconvertible. Considerable financial turmoil enveloped the country for several years while various armed factions fought for control. By the time a new government took power in 1916, bank notes could be exchanged for specie at a small fraction of their pre-1913 par value, and circulated along with currencies issued by competing armies (Kemmerer op. cit.).

During the revolution, there had been various attempts to restore the public's confidence in paper money (see McCaleb op. cit., Kemmerer op. cit.). With the coming to power of Venustiano Carranza in 1916, efforts to reform the banking system began to make some headway. A banking commission was set up to determine which banks, which were in a quite sorry state by this point, had sufficient specie reserves to remain in operation. The ultimate objective, however, was much more far-reaching, to create a government-owned bank with a monopoly on the power to issue notes.

It was believed by Manero and others who were intimately involved in the reform process that many banks had engaged in fraudulent behavior and had been managed poorly, and as a result ran into serious problems before the revolution. One cannot attribute this view entirely to the strained relationship between banks and the Carranza government at that time, as this view had been expressed by Mexico's finance minister before the revolution. Kemmerer (1940 p.19), too, tells us that "Mexico was a country whose banking laws had been carefully drawn, but not so carefully enforced. Partly as a result of banking abuses, and partly as a result of the political and economic disturbances of the period, some of the banks found themselves in a rather unstable position during the early part of the period." Manero and Cerda (1997) were more specific in 
that the state banks were the main objectives of their criticism in this regard.

There are only a couple of cases in which there is any direct evidence of fraud or highly questionable banking practices. Perhaps the best documented case is that of Banco de Campeche, which was a small bank. In 1907, it was revealed that loans to its main shareholder, Jose Castellot, accounted for the lion's share of its capital (Rosenzweig op. cit. p. 853). Rosenzweig's account of the case suggests that Castellot, who was governor of the state of Campeche, never made any attempt to repay his obligations. After being subject to what was obviously weak regulatory pressure to shape up, the bank was finally closed in 1911.

Nonetheless, the belief that the banking system had suffered from behavioral problems before the revolution ran strong (see Manero op.cit.). This view was apparent from the memorandum from F. G. Camacho, a Mexican banking official, to Walter McCaleb around 1920, who concluded that "...it is a matter already extensively debated and practically decided that the system of plurality of Banks of Issue is less efficient than one centralizing the matter of emissions" (McCaleb op. cit. p. 255, italics added for emphasis). The 1917 constitution had already mandated the creation of a government-owned bank with a monopoly over the power to issue notes. As a result, the Banco de Mexico (Mexico's modern-day central bank) was founded in 1925. 


\section{The Working of the BCS}

Regarding the BCS, Manero opined:

It was to be hoped that being the local banks possessing...twothirds of the total capital, that the administration of Central would be totally favorable to their interests. But it was not thus...

Actually, it does not appear that state banks had collectively this large a stake in Banco Central for more than a brief period. Even if they had, one should have expected a fundamental tension among members of a fixed exchange rate system for bank notes, which is what the BCS was essentially intended to be. With notes by member banks being exchangeable at a fixed rate and for specie at par, discounts would no longer signal the creditworthiness of the borrower. Each bank had an incentive to exploit this informational problem for its own gain at the expense of others by issuing more of its notes than what would otherwise have been the case. Eventually, Banco Central's reserves would be exhausted by demands for redemption, and the system would thus collapse. If the BCS was to be viable, there had to be some mechanism for constraining the behavior of member banks. ${ }^{11}$

The BCS was similar to the Suffolk Bank System of New England in that they both involved an agent that redeemed member bank notes at par. The Suffolk System appears to have been the most successful of the bank note redemption systems that operated in the United States before the Civil War, making it a standard for comparison against the BCS. Calomiris and Kahn (op. cit.) provide evidence that the discipline instilled by the Suffolk Bank enabled New England banks to operate more efficiently and enabled their notes to circulate at smaller discounts

11 Zarazaga (1993) studies a similar incentive problem in a model with independent issuers of a common currency under a fiat money regime. 
compared with banks outside the system. I draw heavily on Calomiris' and Kahn's account of the Suffolk Bank System. Since the contracts governing the relationships between Banco Central and its correspondents (to which Conant op. cit. referred in his description) could not be located, I relied on Conant's account, which seems to be the source of Manero's and others' discussions of the BCS.

Relative to the Suffolk Bank System, the BCS seems to have been at a disadvantage in terms of influencing the behavior of member banks in at least one respect. In contrast to the Suffolk Bank System, the BCS was not limited geographically, as Banco Central's statutes required all state banks to be correspondents. Although communications and transportation systems had developed considerably by the turn of the century, it would not have been all that easy for Banco Central to monitor the activities of state banks in the more remote regions. (This would have been an easier task for Banco Nacional, given its branch network.)

According to Conant, Banco Central did not necessarily require payment in specie when it returned state bank notes, essentially permitting overdrafts. However, Banco Central charged interest on overdrafts. ${ }^{12}$ Banco Central's accounts with local banks were balanced once every 6 months (according to Conant). The Suffolk Bank, in contrast, at first required payment in specie. It later allowed overdrafts, but loans had to be repaid each week. As the Suffolk Bank System evolved, the Suffolk Bank had daily clearings and put other restrictions on the volume of notes that could be cleared in one day. According to Calomiris (1989), payments arrangements that allowed overdrafts tended to collapse quickly. However, overdrafts reduced the gain from and

12 The loan rate rose if the balance surpassed 10 percent of the capital the member had paid into Banco Central. 
thus the incentive to "overissue", since they amounted to paying interest on notes. It is not clear whether the BCS would have been a less effective constraint than the Suffolk Bank System in this respect, if access to the overdraft feature had been left to Banco Central's discretion.

Under Banco Central's charter, members could not sell their stakes in Banco Central for ten years. This went some of the way towards alleviating the incentive problem, forcing a member bank to balance its short-term gains from "inflating" against its longer-run interest in ensuring the viability of the system. Each bank was required to hold a small stake in Banco Central. ${ }^{13}$ Judging from Mexican government records, major investors of some banks held considerable stakes in Banco Central, but this does not appear to have been the case for all banks.

An important feature of the Suffolk Bank System was the Suffolk Bank's use of nonprice mechanisms, including the threat of suspension of a member from the arrangement, to help induce good behavior. Conant notes that Banco Central could refuse "notes which [were] presented in abnormal quantities or with suspicious intent" (op. cit. p. 43). However, following an incident that occurred in 1900 involving Banco Yucateco, suspending any member from the par redemption arrangement does not appear to have been considered a politically feasible option. Banco Yucateco's case is an important one, because the bank was relatively large. The case also provides what seems to be the best direct evidence of a bank that did try to exploit the system at the expense of other members.

13 The capital requirement for membership was increased in January 1903 from 5 percent of a member's own capital to 10 percent. In early 1904, however, the requirement was modified such that a member could purchase stock equal to 10 percent of the book value of its capital as of December 1901. The combined equity (book value) of the 19 state banks that existed in June 1901 rose from 26 million pesos at that point to 56 million pesos in June 1907. 


\section{Va. Banco Yucateco and the BCS}

Banco Yucateco (BY) was one of two state banks in the state of Yucatan and had grown to be the largest state bank in 1901. (Banco Nacional also had a branch in that state.) In August 1900, Banco Central began accepting BY's notes for specie at a five percent discount after the state bank notified the Mexico city bank and two other correspondent state banks that it was not able to provide the "funds that were made for the redemption of its notes at par". (Minutes from BY's February 2, 1901 annual shareholders' meeting.) The other two correspondents followed suit.

Although the discount on BY's notes had fallen to only one-half percent in early 1901, this state of affairs was not deemed satisfactory by the bank's management, declaring that "the free exchange and circulation of our notes in the exchanges (plazas) of Mexico [City] and the States of the Republic will not be possible until it is at par" (minutes from BY shareholders' annual meeting 1/29/1902). Management observed that 50 percent of Banco Central's stock was held by [a] foreign syndicate" and stated that "experience has demonstrated the inconveniences of this arrangement". It added that "it has been considered the acquisition of all of the shares and bonds that were in the hands of foreign Banks" (minutes from 2/1/1901 BY shareholders' meeting).

Half of Banco Central's initial placement of shares had been taken up by three foreign investment houses, Deutchebank, Bleichroeder, and J.P. Morgan. Deutchebank and Bleichroeder were major investment houses in Europe. Bleichroeder \& Co. had a longstanding relationship with the Mexican government, having led or helped managed the government's issue of bonds in Europe since the early days of the Diaz administration. According to Carosso (1987), the three 
investment houses had been working together to secure a lead role in the Mexican government's restructuring of bonds held abroad as of early 1898, and so their acquisition of shares in Banco Central may have been made to sweeten the deal. ${ }^{14}$

As a result of a agreement reached in early 1901, the Bleichroeder et al stake passed into the hands of the state banks, with each state bank's contribution being in proportion to its own capital. Exactly how the money was made available is not clear, but BY's management stated that "the terms of payment were flexible" (minutes 1/29/1902), suggesting that it came in the form of a loan. Gurza (op. cit. p. 51) also suggests that the government's role in the arrangement was quite critical:

Although the law... explicitly prohibits that establishment of said agencies in the Federal District [for redeeming state bank notes], the Government not only was not opposed that Banco Central deceitfully had this character, but also, understanding that the union of the local banks was a progress in our banking system, favored the idea of the creation of Banco Central, granting its charter, facilitating its establishment, and giving material help and very marked help when later the new bank hit difficulties, owing to the foreign shareholders wanting to follow a policy counter to the interests of the local banks (italics added for emphasis).

In the years following the 1900 incident, BY was not subject to any further suspensions of convertibility by Banco Central, but its troubles did not end. BY's notes outstanding peaked at 8 million pesos at the end of 1903, but then steadily declined. It had only 2 million pesos in notes outstanding in mid-1907, despite various mechanisms that had been adopted to boost the demand for state bank notes in general and for its notes in particular. In November 1903, BY, Banco Mercantil de Yucatan, and Banco Nacional agreed to accept each others' notes at par

14 The deal, writes Carosso, took 15 months to conclude, in part because the Mexican government was holding out for better terms with rival firms. Ultimately, Bleichroeder and company won the account, and the bonds were marketed in the United States and Europe as the 5 Percent External Consolidated Gold Loan of 1899. 
(BY's annual report to shareholders 2/12/1904). The following April, however, BY notified Banco Nacional that it could not redeem its notes for specie (Cerda op. cit.), and asked for a loan. Banco Nacional's senior executive body postponed its decision. In late May, a newspaper reported that the notes of BY were accepted at par by Banco Mercantil de Yucatan, but observed that the "notes are not exchanged regularly and balances build up". ${ }^{15}$ Although the story does not explicitly say that Banco Mercantil de Yucatan was accumulating BY's notes, it seems reasonable to infer that this had been the case.

As these events unfolded, in March of 1904, representatives of state banks held their first joint meeting in the nation's capital and agreed on what were considered to be wide-ranging changes in the BCS. First, they agreed on a limited the mutual aid scheme that would be administered through Banco Central. ${ }^{16}$ Second, each state bank would accept at par notes of any other state bank. This, according to Rosenzweig (op. cit. p. 828), was intended to "avoid excessive concentration of exchange at Banco Central and reduce to a more manageable level the balances of each bank with Banco Central", which suggests that overdrafts by some banks were reaching unreasonably high levels. The third change was an anti-competitive agreement under which banks agreed to close all branches and agencies in states other than the ones in which they had been originally established. State banks did not follow through on this last commitment, illustrating the difficulties of enforcing collusive agreements (private communication with Noel

15 "El Crédito en Yucatan", El Economista Mexicano, May 28, 1904.

16 Member banks would send specie to Banco Central, so that "the amount thus placed in the hands of the Banco Central [would be] employed in redeeming at par the notes of the establishment which is threatened." (Rosenzweig op. cit. p. 828) Assistance was limited to 50 percent of the book value of capital of the bank in need and to 2 percent of the book value of the capital of the contributing bank. 
Maurer).

Federal regulators tabulated the volume of state bank notes purchased by Banco Central in the second half of 1905, and show that it purchased more BY notes than those of any other bank. Some rough calculations suggest that while it took roughly 6 months for a note issued by Banco Mercantil de Yucatan to be presented to Banco Central for redemption, a note issued by BY passed through Banco Central two and a half times more quickly. Thus, BY had more trouble keeping its note in circulation than did Banco Mercantil de Yucatan.

While BY's notes in circulation continued to decline after 1904, its other liabilities did not. Bank balance sheets did not distinguish among various types of non-bank note liabilities in any meaningful way, so it is impossible to know for sure how BY obtained its funding.

However, Banco Nacional had provided each of the Yucateco banks with sizeable loans in 1906 (Cerda op. cit.). In the bank's 1906 report to shareholders, BY stated that it "suspended the circulation of...notes in the Capital of the Republic", adding that it could not hope to keep its notes in circulation as long as they were being sent immediately to Banco Central for redemption. Management also suggested the move had come in response to official pressure (2/19/1907, 1906 shareholders report).

By 1907 economic conditions in the Yucatan peninsula had deteriorated to the point where both BY and Banco Mercantil de Yucatan were in trouble. ${ }^{17}$ In mid-1907, according to Barcelo Quintal (1986), the French financiers that held a large stake in Banco Nacional had also acquired a stake in BY and replaced the management of both of the Yucateco banks. In early

17 The gold price of sisal (hemp fiber), the region's most important export commodity, had fallen by 30 percent between 1902 and 1904, and by another 30 percent by 1907. (Data from Askinasy 1936, reproduced in Barcelo Quintal op. cit. pp 192-3.) 
1908, the two banks were merged. Barcelo Quintal's characterization of the event suggests that the merged bank was recapitalized with the help of French investors.

\section{Vb. Further Evidence of Government Involvement in the BCS}

The state banks' purchase of the Bleichroeder et al stake in Banco Central would have left state banks holding two-thirds of the bank's shares as of early 1901. However, there were subsequent capital increases that were taken up by outside shareholders. According to Conant (op. cit. p. 45), these issues 'were taken up by foreign syndicates [that] did not interfere with the local management of the bank'. In mid-1905, Banco Central more than doubled its capital, raising it from 10 million pesos to 21 million pesos, with nearly half of the shares issued being taken up by the Banque de l'Union Parisienne. According to El Economista Mexicano (June 23, 1905), Banque de l'Union was to ensure that the shares could be traded in the Paris exchange, but that French interests would be represented by the French bank. Prior to the capital subscription, Banco Central's statutes were amended to give state banks collectively a majority on its senior executive board (Consejo de administracion). Why outside shareholders would have been willing to agree to dilution of their representation on the board is left unexplained. It is reasonable to speculate that there was an implicit or explicit understanding that the Diaz government would protect their interests.

Cerda (op. cit.) notes that beginning around 1904, Banco Nacional became more active in providing loans to other banks. Banco Nacional was subject to pressures from the Mexican government to provide certain loans from time to time, which, according to Maurer (1997), it

mostly resisted. In mid-June, however, Banco Nacional granted a loan to Banco Central for one and a half million pesos two weeks after it had refused an earlier request for a smaller loan 
(Cerda op. cit. p. 430). Government bank records suggest that a correspondent relationship existed between the two banks, and thus, Banco Central's request for a line of credit "to facilitate the daily exchange of documents" suggested that it was seeking overdraft protection (Cerda op. cit. p. 430) The line of credit was renewed at the end of the year.

Cerda does not mention whether there was any discussion of official pressure on the bank to provide the loan to Banco Central, but its timing and the fact that Joaquim Casasus had requested the renewal of the line of credit suggests that this was the case. Casasus was intimately involved in the BCS, having represented the local banks in negotiations with the Bleichroeder syndicate and acting as a member of its executive board. Casasus was also closely associated with the Diaz government. A former legislator, Casasus had presided over the commission that drafted the 1896 bank law, and fulfilled other roles during his distinguished career, including that of the Mexican Ambassador to the United States around 1905.

Despite the suggestion of official intervention to help Banco Central, Table 2 does not suggest that Banco Central acted as though freed from the constraint of profit-maximization to pursue other objectives. Although the bank's liabilities relative to its specie reserves increased substantially after 1901, subsequent capital increases enabled it to maintain a fairly constant ratio of liabilities to (book) capital. ${ }^{18}$ However, the balance sheets do not give a complete picture of the financial situation of the bank. In 1906, Banco Central established the Compania Bancaria de Obras y Bienes Raices, which was a banking company (1906 shareholders' report 4/10/1907). Banking companies were depository institutions that were not regulated, and their books were

18 Since specie reserves included holdings of other banks' notes before 1901, the increase thereafter is exaggerated to some degree. 
not consolidated with those of chartered banks even through there may have been a close relationship between the two entities. McCaleb (op. cit. p. 201) states that in 1909, it became widely known that Banco Central had suffered large losses through the operations of the banking company.

\section{Evidence of Behavioral Problems Under the System}

The evidence seems quite compelling that official intervention blunted the disciplinary role of Banco Central in the system, but how severe resulting behavioral problems were remains unclear. Comparing measures of risk of the two Yucateco banks, which were exposed to the same underlying risks, shed some light into the issue. As seen in Table 3, particularly before 1904, the ratio of notes to specie reserves and to (book) capital were higher for BY than for Banco Mercantil de Yucatan. Despite the difficulties in interpretation, the same comparison was made with total liabilities in the numerator. BY's total liabilities to specie reserves and to capital again often exceeded that of its Yucateco competitor. That is, abstracting from events affecting both banks (and marked changes in these ratios suggests that these events were important), Banco Yucateco pursued a relatively risky strategy.

Risk measures of all state banks were also compared with the two city banks. Tables $4 \mathrm{a}$ and $4 \mathrm{~b}$ compare note-to-specie ratios and note-to-market capital ratios of the state banks with those of Banco Nacional and Banco de Londres. After 1901, state banks tended to have higher ratios of notes to specie and higher ratios of specie to market capital than did the city banks. Total liabilities of banks were also looked at (results not shown), even though Banco Nacional's role as a federal treasury agent makes it hard to interpret the results. If one ignores Banco 
Nacional (whose risk was the highest by this measure), state banks tended to have higher ratios of liabilities to specie and to market capital than did Banco de Londres. The ratios are not reported after 1904 because Banco Nacional's role in management of the bimetallic standard adopted in 1905 would make the results hard to interpret.

Because it could be that state banks tended to be more risky because they were more vulnerable than were the city banks to underlying economic conditions (because city banks were better diversified), an attempt was made to account for bank-specific risk with panel estimations. The observations were from December of each year. Four measures of bank risk for which data are available over the 1897 to 1904 period were used as dependent variables: notes relative to specie, total liabilities relative to specie, notes relative to book capital, and total liabilities relative to book capital. These measures were regressed on bank dummies, time dummies, and a dummy variable that was equal to one if an observation represented a state bank after 1900 and zero otherwise (statebank01). If the coefficient associated with statebank01 was positive and significant, it was interpreted as meaning that state banks tended to be riskier after 1900 than city banks.

The results weakly support the hypothesis that even after controlling for year and bank specific factors, state banks tended to have higher levels of risk after 1900. Although the coefficient on the interactive dummy was always positive, the only case in which it was not significantly different from zero was when note/specie was the dependent variable. The lack of statistical significance probably reflects the tests' low power; only two banks are alternatives to the state banks (with varied in number from 7 in 1897 to a peak of about 25).

Graph 1 attempts to give a better picture of what was going on in the regression in which 
the note-to-specie ratio was the dependent variable. Another model was estimated to include only the state banks with the note-to-specie ratio as the dependent variable. Time and bank dummies were constructed such that one could interpret the year intercepts as changes in the average state bank note-to-specie ratio relative to its 1897 level. These numbers (the year intercepts) are plotted in Graph 1. The plot shows that once state bank specific effects are accounted for, the note-to-specie ratio (on average) generally rose after 1897. (This result also holds when removing the Yucateco banks.) The state bank average (relative to 1897) is compared with those of Banco Nacional and Banco de Londres.

One could interpret the rise in state banks' average note-to-specie ratio (relative to 1897) either as a sign of rising risk-taking or as a sign of greater confidence in state bank notes. If investors were more confident about the safety of state bank notes, state banks would have been able to issue more notes with fewer specie reserves to back them (as was the case with banks in New England under the Suffolk Bank System). However, if this had been the case, then there would not have been any need for the alterations that were made to the system in the early $1900 \mathrm{~s}$ to keep state bank notes circulating at par. Thus, in my view, the graph suggests that at least in 1903 and 1904, the city banks behaved in a more conservative manner than the state banks.

\section{Conclusion}

Overall, the evidence suggests that government intervention muted Banco Central's effectiveness as a source of discipline on state bank behavior. By 1908, Mexico's government had come to the conclusion that the BCS was in need of reform. Among several amendments to the 1896 law that were approved in June of that year by congress was one that addressed the note 
exchange process. The amendment stated that banks of issue would "periodically exchange the notes of other banks in their possession and shall, in the absence of express agreement between the parties, pay the balances in cash" (Conant op. cit. p. 177). Further details were to be forthcoming, but the reform initiative obviously lost favor during the revolution. ${ }^{19}$

Because BCS was government mandated and government influenced, the Mexican experience provides little insight into the viability of private payments systems. How costly government involvement in the BCS ultimately turned out to be (in terms of muting members' incentives to act conservatively) is impossible to determine, since even a well-designed private payments system may have had trouble coping with the crisis period of 1907-08. The most likely source of problems during this period was the government's decision to adhere to the bimetallic standard in the face of adverse shocks (including wide variations in the gold to silver price ratio). A closer look at this and other causes of Mexico's banking problems in the early 1900 s is left, however, for future research.

${ }^{19}$ Casasus (op. cit p. 190) suggested that all banks, except for Banco Nacional, meet once or twice per month in Mexico City to exchange their notes. He also suggested that the notes of Banco Nacional or drafts on Mexico City payable by Banco Central could be used to settle adverse balances. 
Table 1a State Banks That Received Federal Charters Between 1889 and 1891

\begin{tabular}{|c|c|c|}
\hline Bank & $\begin{array}{l}\text { States where authorized to } \\
\text { establish branches }\end{array}$ & $\begin{array}{l}\text { Year federal charter } \\
\text { approved }\end{array}$ \\
\hline \multicolumn{3}{|l|}{ Chihuahua } \\
\hline $\begin{array}{l}\text { Banco Comercial de } \\
\text { Chihuahua }\end{array}$ & Not specified by charter & $\begin{array}{l}1889 \text { (previously Banco de } \\
\text { Santa Eulalia } 1875-89 \text {, } \\
\text { chartered by the legislature } \\
\text { of Chihuahua) }\end{array}$ \\
\hline Banco Minero de Chihuahua & Not specified by charter & $\begin{array}{l}1888 \text { (previously had been } \\
\text { chartered by the legislature } \\
\text { of Chihuahua) }\end{array}$ \\
\hline $\begin{array}{l}\text { Banco Mexicano de } \\
\text { Chihuahua }\end{array}$ & Not specified by charter & $\begin{array}{l}1888 \text { (previously had been } \\
\text { chartered by the legislature } \\
\text { of Chihuahua) }\end{array}$ \\
\hline \multicolumn{3}{|l|}{ Yucatan } \\
\hline Banco Yucateco & $\begin{array}{l}\text { Yucatan, Campeche, and } \\
\text { Tabasco }\end{array}$ & $\begin{array}{l}1889 \text { (previously a } \\
\text { commercial house) }\end{array}$ \\
\hline Banco Mercantil de Yucatan & $\begin{array}{l}\text { Yucatan, Campeche, and } \\
\text { Tabasco }\end{array}$ & $\begin{array}{l}1889 \text { (previously a } \\
\text { commercial house) }\end{array}$ \\
\hline \multicolumn{3}{|l|}{ Durango } \\
\hline Banco de Durango & Durango & $\begin{array}{l}1890 \text { (opened for business } \\
9 / 90 \text { ) }\end{array}$ \\
\hline \multicolumn{3}{|l|}{ Zacatecas } \\
\hline Banco de Zacatecas & $\begin{array}{l}\text { Zacatecas and } \\
\text { Aguascalientes }\end{array}$ & $\begin{array}{l}1891 \text { (opened for business } \\
12 / 91 \text { ) }\end{array}$ \\
\hline \multicolumn{3}{|l|}{ Nuevo Leon } \\
\hline Banco de Nuevo Leon & $\begin{array}{l}\text { Nuevo Leon, Coahuila, and } \\
\text { Tamaulipas }\end{array}$ & $\begin{array}{l}1891 \text { (opened for business in } \\
10 / 92 \text { ) }\end{array}$ \\
\hline
\end{tabular}


Table 1b: State Banks That Received Federal Charters Under 1896 Bank Law

\begin{tabular}{|c|c|c|}
\hline Bank & $\begin{array}{l}\text { States where allowed to open } \\
\text { branches and agencies }\end{array}$ & Opening Date \\
\hline 1. Banco del Estado de Mexico & $\begin{array}{l}\text { Mexico (state), Hidalgo, } \\
\text { Puebla, Michoacan, and } \\
\text { Veracruz }\end{array}$ & $8 / 1897$ \\
\hline 2. Banco de Coahuila & Coahuila & $10 / 1897$ \\
\hline 3. Banco de San Luis Potosi & $\begin{array}{l}\text { San Luis Potosi; could also } \\
\text { establish a branch in } \\
\text { Guanajuato }\end{array}$ & $10 / 1897$ \\
\hline 4. Banco de Sonora & Sonora & $1 / 1898$ \\
\hline 5. Banco Occidental de Mexico & $\begin{array}{l}\text { Sinaloa and could establish a } \\
\text { branch in Sonora }\end{array}$ & 2/1898 \\
\hline 6. Banco Mercantil de Veracruz & Veracruz & $3 / 1898$ \\
\hline 7. Banco de Jalisco & $\begin{array}{l}\text { Jalisco, and one agency in } \\
\text { Celaya (state of Guanajuato) } \\
\text { "for exchange of notes". } \\
\text { 12/3/98: Celaya agency was } \\
\text { converted into a full service } \\
\text { branch. } 1899: \text {, could establish } \\
\text { branches in the territory of } \\
\text { Tepic. Also later established } \\
\text { branch in the state of } \\
\text { Michoacan }\end{array}$ & $11 / 1898$ \\
\hline 8. Banco Mercantil de Monterrey & $\begin{array}{l}\text { Nuevo Leon, Coahuila } \\
\text { Tamaulipas, and Durango }\end{array}$ & $12 / 1899$ \\
\hline 9. Banco Oriental de Mexico & $\begin{array}{l}\text { Puebla (opened branch in } \\
\text { Oaxaca in 1901) }\end{array}$ & $3 / 1900$ \\
\hline 10. Banco de Guanajuato & Guanajuato, Jalisco, Michoacan & $8 / 1900$ \\
\hline 11. Banco de Tabasco & Tabasco & $1 / 1901$ \\
\hline 12. Banco de Chiapas & Chiapas & $2 / 1902$ \\
\hline
\end{tabular}


Table 1b: State Banks That Received Federal Charters Under 1896 Bank Law

\begin{tabular}{|c|c|c|}
\hline Bank & $\begin{array}{l}\text { States where allowed to open } \\
\text { branches and agencies }\end{array}$ & Opening date \\
\hline 13. Banco de Aguascalientes & $\begin{array}{l}\text { Aguascalientes; could establish } \\
\text { one branch in the state of } \\
\text { Guadalajara }\end{array}$ & 9/1902 \\
\hline 14. Banco de Tamaulipas & Tamaulipas & $10 / 1902$ \\
\hline 15. Banco de Hidalgo & Hidalgo & $11 / 1902$ \\
\hline 16. Banco de Oaxaca & Oaxaca & $11 / 1902$ \\
\hline 17. Banco de Michoacan & Michoacan & 1902 \\
\hline 18. Banco de Morelos & $\begin{array}{l}\text { Cuernavaca; could establish } \\
\text { one branch in Acapulco (state } \\
\text { of Guerrero) }\end{array}$ & $3 / 1903$ \\
\hline 19. Banco de Queretaro & & $7 / 1903$ \\
\hline 20. Banco de Campeche & & 8/1903 \\
\hline 21. Banco de Guererro & & 1905 \\
\hline
\end{tabular}

Sources: Gurza (1905), Secretaria de Hacienda, Memoria de Hacienda, various dates, The Banker, various dates. 
Table 2 Total liabilities of Banco Central relative to specie and to book capital (December of each year)

\begin{tabular}{lll}
\hline & Liabilities/specie* & Liabilities/book capital ** \\
\hline 1899 & 2.7 & 1.6 \\
1900 & 3.5 & 0.9 \\
1901 & 5.8 & 1.3 \\
1902 & 14.5 & 2.4 \\
1903 & 15.0 & 1.7 \\
1904 & 15.0 & 1.7 \\
1905 & 21.9 & 1.2 \\
1906 & 33.1 & 1.5 \\
1907 & 42.9 & 1.6 \\
$*$ specie includes holdings of other bank notes prior to 1901 & \\
$* *$ book capital = paid in capital plus reserves &
\end{tabular}


Table 3. Risk Measures of Banks in the State of Yucatan

\begin{tabular}{lllllllll} 
& \multicolumn{2}{c}{ Notes/specie } & \multicolumn{2}{c}{ Liabilities/specie } & \multicolumn{2}{c}{ Notes/book capital } & \multicolumn{2}{c}{ Liabilities/book capital } \\
Year & Banco & Banco & Banco & Banco & Banco & Banco & Banco & Banco \\
& Yucateco & Mercantil & Yucateco & Mercantil & Yucateco & Mercantil & Yucateco & Mercantil \\
\hline 1897 & 1.79 & 1.53 & 2.72 & 1.92 & 1.42 & 1.40 & 2.15 & 1.76 \\
1898 & 1.77 & 1.32 & 2.70 & 1.78 & 2.57 & 1.63 & 3.91 & 2.20 \\
1899 & 1.76 & 1.37 & 2.79 & 2.20 & 2.45 & 1.91 & 3.87 & 3.06 \\
1900 & 1.86 & 1.52 & 2.72 & 2.12 & 1.83 & 1.28 & 2.68 & 1.80 \\
1901 & 1.82 & 1.68 & 2.97 & 2.68 & 1.12 & 1.02 & 1.82 & 1.63 \\
1902 & 1.70 & 1.58 & 3.11 & 3.17 & 1.14 & 0.80 & 2.07 & 1.61 \\
1903 & 1.81 & 1.68 & 3.85 & 3.78 & 0.52 & 0.38 & 1.11 & 0.85 \\
1904 & 1.71 & 1.66 & 4.21 & 4.24 & 0.44 & 0.63 & 1.08 & 1.61 \\
1905 & 2.74 & 1.57 & 7.99 & 4.61 & 0.52 & 0.37 & 1.50 & 1.10 \\
1906 & 1.66 & 1.69 & 6.80 & 5.40 & 0.18 & 0.31 & 0.72 & 1.00 \\
1907 & 1.73 & 1.69 & 6.34 & 4.62 & 0.17 & 0.24 & 0.62 & 0.65 \\
\hline
\end{tabular}

book capital =paid in capital plus reserves 
Table 4a Notes Relative to Specie Reserves

\begin{tabular}{lllllll}
\hline \multicolumn{3}{l}{ State Banks } & & & & $\begin{array}{l}\text { Banco } \\
\text { Nacional }\end{array}$ \\
Year & No. Obs. & Median & Mean & Std. Dev. & $\begin{array}{l}\text { Banco de } \\
\text { Londres }\end{array}$ \\
\hline 1897 & 7 & 1.55 & 1.51 & 0.34 & 1.11 & 1.67 \\
1898 & 13 & 1.59 & 1.45 & 0.42 & 0.82 & 1.89 \\
1899 & 13 & 1.49 & 1.49 & 0.31 & 0.90 & 1.70 \\
1900 & 15 & 1.74 & 1.70 & 0.34 & 0.93 & 1.59 \\
1901 & 17 & 1.69 & 1.74 & 0.37 & 1.33 & 1.04 \\
1902 & 21 & 1.67 & 1.64 & 0.44 & 1.62 & 1.82 \\
1903 & 26 & 1.73 & 1.74 & 0.30 & 0.96 & 1.60 \\
1904 & 26 & 1.71 & 1.76 & 0.22 & 0.62 & 1.20 \\
\hline
\end{tabular}

Table 4b Notes Relative to Market Capital

\begin{tabular}{lllllll}
\hline \multicolumn{3}{c}{ State Banks } & & & $\begin{array}{l}\text { Banco } \\
\text { Nacional }\end{array}$ & $\begin{array}{l}\text { Banco de } \\
\text { Londres }\end{array}$ \\
Year & No. Obs. & Median & Mean & Std. Dev. & \\
\hline 1900 & 15 & 0.89 & 1.08 & 0.77 & 0.58 & 0.76 \\
1901 & 16 & 0.82 & 1.07 & 0.61 & 0.47 & 0.60 \\
1902 & 21 & 0.84 & 1.02 & 0.51 & 0.46 & 0.64 \\
1903 & 22 & 0.84 & 0.97 & 0.45 & 0.35 & 0.69 \\
1904 & 26 & 0.95 & 1.01 & 0.55 & 0.31 & 0.60 \\
\hline
\end{tabular}




\section{Graph 1: Notes/Specie} (change relative to 1897)

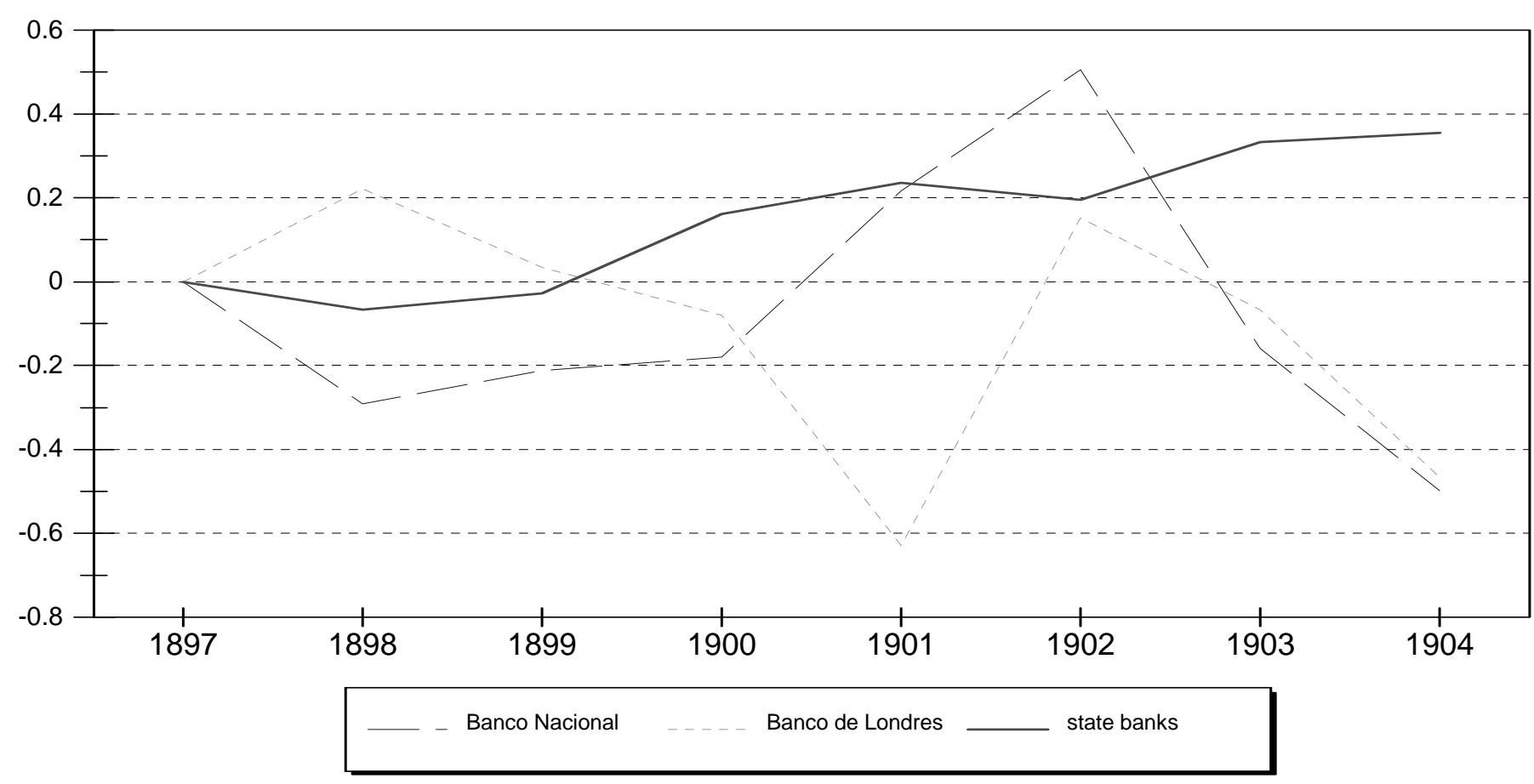




\section{Appendix 1: Historical Setting}

Throughout the nineteenth and early twentieth centuries, Mexico remained for the most part a small economy that was heavily dependent on mining and agriculture. Silver and other minerals accounted for three-quarters of Mexico's exports in the early 1880s (declining to twothirds by 1900), and agricultural commodities accounted for most of the rest. In terms of per capita income, Mexico was roughly two-fifths the size of the United States in 1800, but was only one-eighth its size in $1895 .^{20}$

Financial and economic development came late to Mexico, which experienced many episodes of internal strife and military conflicts with foreign powers for nearly six decades after independence from Spain in 1820. Domestic strife, poor infrastructure, and interstate tariffs (alcabadas) limited growth and interregional trade over most of the 1800s. The lack of navigable waterways and Mexico's mountainous terrain also made travel slow and difficult. Mexico was a rural nation, with less then 30 percent of its population of 15 million living in urban areas in 1910, but the central region of the country was relatively densely populated. As of 1878, there were over 50 localities with populations of over 15 thousand, most of which were located in the neighboring states of Jalisco, Guanajuato, Queretaro, and San Luis Potosi in the central region of the country. ${ }^{21}$

${ }^{20}$ Source of data here and below unless otherwise stated is the Mexican government, Estadísticas Históricas de Mexico, 1985.

21 Although Mexico City had close commercial links with the port of Veracruz (roughly 500 miles to the southeast), had fewer ties with the more remote regions. For instance, one report in 1882 posted from Ciudad Chihuahua near the U.S. border stated that the area was isolated from the rest of Mexico, but was connected to all parts of the United States by railroad and telegraph (The Mexican Financier, November 16, 1882). 
Judging from McCaleb (op. cit.), payments more than occasionally involved shipments of specie. The high cost of sending specie from one location to another would have encouraged the development of more economical payments mechanisms. A limiting factor appears to have been the high risk of default. Casas de comercio (commercial houses) made loans to hacendados (owners of large estates) and to the government at exorbitant rates at times (see Tennenbaum 1986), and some casas funded their operations by circulating liabilities called vales. Vales evolved into bearer notes that were redeemable for some type of commodity money (usually gold or silver coin) on demand (see Barceló Quintal 1986, Lobato Lopez 1945). According to Lobato Lopez, bankruptcies among casas seem to have been a common phenomenon for reasons he does not make clear, but probably were the result of adverse economic conditions. Another important impediment to the development of the financial system was the lack of an adequate framework for specifying and enforcing property rights (see Haber op. cit. p. 567).

Banco de Londres y Mexico was the first major financial intermediary able to issue notes that were widely accepted, for Martinez Sobral (op. cit. p. 25) tells us it was not long after Banco de Londres began operations in the 1860s that its notes "were always guaranteed, and the exchange of the notes was carried out without any difficulty". Nonetheless, bank notes did not supplant coins as a means of payment until around $1900 .^{22}$

The economic and financial landscape underwent a dramatic transformation with the arrival of political stability in the 1880 s. In 1877 , General Porfirio Diaz seized power in a military struggle. After stepping down in 1880, Diaz was elected president in 1884, and served

22 Mexican silver peso coins circulated throughout the world in the nineteenth century, and no serious attempt was made to determine the amount held domestically until 1903 (see Kemmerer 1916). 
several consecutive terms in office until he was forced into exile in 1911. Political stability and greater access to capital from abroad made possible sizeable investments in infrastructure and stimulated development in other areas of economic activity.

Before 1897, several banks of issue operated throughout Mexico, but entry into the business of issuing notes was restricted and a bank of issue was of uncertain legal validity. The legal quandary had existed since 1884, when Mexico’s first federal banking law was passed by the national legislature in response to a financial crisis. The new law required all existing issuers of demandable notes to obtain a federal charter to become a bank of issue and greatly enhanced the position of Banco Nacional de Mexico. Banco Nacional had received a federal charter in 1881 as a result of the federal government's efforts to secure financing from abroad. ${ }^{23}$ The 1884 law imposed a considerable note tax on all other issuers of notes and prohibited new banks of issue (other than the private issuers that could stay in business as long as they obtained a federal bank charter). ${ }^{24}$ These provisions were incorporated into Banco Nacional's charter, which was renegotiated in 1884 .

For several years, the 1884 law was challenged in political and legal arenas on the grounds that it was unconstitutional and violated states' rights (Barcelo Quintal op. cit. P. 184,

23 Banco Nacional Mexico was opened in 1881 after the federal government awarded D. Eduardo Noetzlin, the representative of the Franco-Egyptian Bank, a bank charter. Following a financial crisis in 1884, the bank was merged with another bank to form Banco Nacional de Mexico. According to Marichal (1986), two-thirds of Banco Nacional's stock was held abroad in the late eighteenth and early nineteenth centuries. See Ludlow (1986) on the origins of Banco Nacional de Mexico.

${ }^{24}$ The law required a bank to pay a 5 percent tax on notes that it was authorized to put into circulation, so the effective tax on outstanding notes could have been much higher. The note tax was 10 percent for non-bank (i.e., unchartered) issuers of notes. 
Manero op. cit.). The legal dispute between Banco de Londres and Banco Nacional entered philosophical dimensions, generating a famous debate on question of whether it was more desirable to have a monopoly over the power to issue notes or allow competitive currencies (see Rosenzweig op. cit.). There was at least one attack on Banco Nacional as a foreign institution. ${ }^{25}$ In the face of such opposition, in 1888, the national congress gave the Executive the power to grant bank charters at its discretion for two years, even though this violated the terms of Banco Nacional's charter. The following year, the banking provisions were removed altogether from the commercial code with the notice that new banking legislation would be forthcoming.

By the early 1890s, the federal government had succeeded to some degree in establishing its authority to regulate banks. All issuers of notes had federal bank charters. Several state banks were operating in Mexico in the 1890s, and were concentrated in the region along the U.S. border (in the states of Chihuahua and Nuevo Leon in particular), in the interior northern region (in Durango and Zacatecas), and in the Yucatan peninsula.

Soon after Jose Yves Limantour became finance minister in May 1892, the federal government suspended the granting of bank charters in view of the legal issues they raised. ${ }^{26}$ In early 1896, a six-member commission was created to draft the new bank law; members of the commission included executives from Banco Nacional and Banco de Londres. On June 3, 1896,

25 In 1889, a book by Luis Labastida was published with a proposal for a new bank law, as the author had been commissioned by the federal government to come up with one. The book appears to be most well-known, however, for its attack on Banco Nacional. Labastida wrote that the institution that represented the interests of foreign investors, and that the bank was unconstitutional. The book, writes Gurza (1905 p. 28), "caused a profound sensation in commercial circles".

${ }^{26}$ Report on the Banking System of Mexico by the Secretary of Finance Yves Jose Limantour to Congress, November 15, 1897, in Conant op. cit. 
President Diaz signed a decree containing general guidelines for the General Law of the Institutions of Credit, authorizing federal charters to be granted to banks operating in the states and territories under certain conditions. The decree also authorized the Executive "to make arrangements with the National Bank of Mexico, by virtue of which and on payment of the compensation what may be considered equitable, all conflict shall be terminated between the privileges of that bank and the provisions of the general law...". ${ }^{27}$ Two weeks later, Banco Nacional's shareholders voted to amend the bank's charter to state that the provisions referring to other banks of issue applied only to ones that were chartered to operate in Mexico City. According to McCaleb (op. cit. p. 98), the draft of the new bank law was approved by congress with little debate, and was promulgated in March 1897.

27 Translation from Conant (op. cit. p. 171) 


\section{Appendix 2: Taxes and Legal Requirements for Banks of Issue Under the 1896 Law}

The 1896 bank law liberalized the rules for entry into the banking system for a bank of issue (i.e., for state banks), but still required them to obtain a charter, and capital requirements plus taxes made it difficult to establish more than one bank per state. The first bank that was established in each state or territory was exempted from a 2 percent annual tax on the book value of paid in capital. The banks already operating in the states of Yucatan and Chihuahua were the exceptions, having been grand fathered into the law. ${ }^{28}$ From 1896 to 1908 , the minimum capital requirement was 500 thousand pesos, which was about 250 thousand U.S. dollars. This was about two-and-a half times the minimum for national banks in the United States in the early 1900s (Haber op. cit. p. 568 fn. 20).

The available information indicates that notes issued by city banks were taxed at a lower rate than notes issued by state banks. The 1896 bank law stipulated that notes that were put in circulation were subject to a stamp tax that would be determined by separate legislation, but at a maximum would be five centavos per note (Martinez Sobral op. cit.). (One centavo was one onehundredths of a peso.) Since the stamp tax laws that were in effect in the early 1900s appear to have imposed a much higher tax on bank notes, the five centavo maximum would have been binding (De la Torre 1902). McCaleb (op. cit. p. 109) also suggests that the stamp tax was five centavos regardless of the denomination of the note. In contrast, city banks' notes were taxed $1 / 2$ centavo for denominations up to fifty pesos, and one centavo for one hundred- to one thousandpeso notes. Essentially, the tax rate on city banks' notes was one-tenth the tax rate on state

${ }^{28}$ Banco de Nuevo Leon refused to go submit to the requirements of the new law, and retained its original charter. A second bank that was chartered in the state of Nuevo Leon was also considered a "first" bank. 
banks' notes for lower denominations (5 to 20 pesos), and one-fifth the rate on state banks' notes for higher denominations (50 to 1,000 pesos). Therefore, except for Banco Nacional's one- and two-peso notes, the city banks were subject to a note tax of at most one-tenth of one percent. 


\section{Bibliography}

Barcelo Quintal, Raquel Ofelia. "El desarrollo de la banca en Yucatan: el henequen y la oligarquia henequenera." In Banca y poder en Mexico (1800-1925), edited by Leonor Lodlow and Carlos Marichal. Mexico City: Grijalbo Enlace, 1986.

Barrera Lavalle. Estudios sobre el origen, desarollo, y legislación bancaria. Mexico: D. Garcia and Co., 1909.

Calomiris, Charles. "Deposit Insurance: Lessons from the Record." Federal Reserve Bank of Chicago Economic Perspectives (May/June 1989), 10-30.

, and Charles Kahn. "The Efficiency of Self-Regulated Payments Systems: Learning from the Suffolk System." Journal of Money, Credit, and Banking 28 (November 1996, Part 2), 766-797.

Carosso, Vincent P. The Morgans: Private International Bankers 1864-1913. Cambridge, Mass.: Harvard University Press, 1987.

Casasus, Joaquin D. La reforma monetaria en Mexico: Informes presentados a la Comision Monetaria y redactados por Joaquin D. Casasus, Presidente de la Cuarta Subcomision, Mexico: Imprenta de Hull, 1905.

. Las Reformas a la Ley de Instituciones de Crédito. From articles published in the newspaper El Tiempo. Mexico City: Tip. De la Oficina Impresora de Estampillas, 1908.

Cerda, Luis. Historia Financiera del Banco Nacional de Mexico. Mexico City: Fomento Cultural Banamex, A.C., 1997.

Conant, Charles. "The Banking System of Mexico." In Banking in Belgium and Mexico. Washington, D.C.: National Monetary Commission Vol. XVI, 1911.

Cowen, Tyler, and Randall S. Kroszner. "Scottish Banking before 1845: A Model for LaissezFaire?" Journal of Money, Credit, and Banking 21 (May 1989), 221-231.

Federal Reserve Board. Statement by Alice M. Rivlin, Vice-Chair, Board of Governors of the Federal Reserve System, before the Subcommittee on Domestic and International Monetary Policy of the Committee on Banking and Financial Services, U.S. House of Representatives, September 16, 1997. Reprinted in the Federal Reserve Bulletin 83 (November 1997), 878-884.

Gurza, Jaime. Nuestros Bancos de Emisión. Mexico: Imprenta Central, 1905. 
Haber, Stephen H. "Industrial Concentration and the Capital Markets: A Comparative Study of Brazil, Mexico, and the United States, 1830-1930." The Journal of Economic History 51 (September 1991) 559-580.

Instituto Nacional de Estadística Geografia e Informática. Estadísticas Históricas de Mexico, Mexico City, 1985.

Kemmerer, Edwin Walter. Modern Currency Reforms. New York: The MacMillan Co., 1916. . Inflation and Revolution: Mexico's Experience of 1912-17. Princeton; Princeton University Press, 1940.

Lelo de Larrea, Enrique. Diccionario de Derecho Mercantil. Mexico: Aguilar y Hijos, 1884.

Lobato Lopez. El crédito en Mexico: esbozo histórico hasta 1925. Mexico: Fondo de Cultura Económica, 1945.

Ludlow, Leonor. "La construcción de un banco: el Banco Nacional de México (1881-1884)." In Ludlow and Marichal, op. cit.

Manero, Antonio. La Revolución Bancaria en Mexico, Mexico City: Talleres Graficos de la Nación, 1957.

Marichal, Carlos. "El nacimiento de la banca mexicana en el contexto latinoamericano: problemas de periodización." In Ludlow and Marichal, op. cit.

Martinez Sobral, Enrique. Estudios Elementales de Legislación Bancaria. Mexico City: Tipografia de la Oficina Impresora de Estampillas, 1911.

Maurer, Noel. "Finance and Oligarchy: Banks, Politics, and Economic Growth in Mexico, 1876-1928." PhD dissertation, Stanford University, 1997.

McCaleb, Walter Flavius. Present and Past Banking in Mexico. New York: Harper and Brothers, 1920.

Mullineaux, Donald. "Competitive Monies and the Suffolk Bank System: A Contractual Perspective." Southern Economic Journal (April 1987) 884-898.

Rosenzweig, Fernando. "Moneda y bancos." In Historia moderna de Mexico, edited by Daniel Cosio Villegas. Mexico City: Ed. Hermes 1965, Vol VII, Tome II, 789-885.

Schell, William Jr. "Money as Commodity: Mexico's Conversion to the Gold Standard, 1905." Mexican Studies 12 (Winter 1996), 67-89. 
Secretaria de Hacienda y Crédito Publico, Inspección General de Instituciones de Crédito y Companias de Seguros, Mexico. Memorias de las Instituciones de Crédito, 1897-1908, 1911.

Selgin, George A., and Lawrence H. White. "How Would the Invisible Hand Handle Money?" Journal of Economic Literature 32 (December 1994), 1718-49.

Tennenbaum, Barbara. "Banqueros sin bancos: el papel de los agiotistas en Mexico (18261854)." In Ludlow and Marichal op. cit.

White, Lawrence H. Free Banking in Britain: Theory, Experience and Debate, 1800-1845. Cambridge: Cambridge University Press, 1984.

Zarazaga, Carlos E. "Hyperinflations and Moral Hazard in the Appropriation of Seigniorage", Federal Reserve Bank of Philadelphia Working Paper No. 93-26. 